\title{
Implications of geochemical signatures in the Trans-Himalayan Lohit batholith, Arunachal Pradesh, India
}

\section{TK Goswami}

Department of Geology, JB College, Jorhat, Assam, INDIA

Email:taposgoswami@yahoo.com

The Trans Himalayan Lohit batholith studied both in the Lohit and Dibang valley gives an insight as far as the source characteristics of magma and the possible evolutionary trend. The batholth represents at least four phases of intrusion representing changing sources of magma generation. The early gabbro-quartz diorites are followed by trondhjemite and followed by intrusions of leucogranites towards the end phase. The aplite and the pegmatite dykes finally intruded all the earlier intrusive. The rocks are metaluminous and mostly calc-alkaline and a few early gabbros also show tholeitic parentage. Gabbro-quartz diorites form a single group with the $\mathrm{SiO}_{2}$ range from 40.34 to $59.64 \%$. Leucogranites show high values of $\mathrm{Rb}, \mathrm{Ba}$ and $\mathrm{K}_{2} \mathrm{O}$. Four samples of diorites and granodiorites have $87 \mathrm{Sr} / 86 \mathrm{Sr}$ initial ratios from 0.7039 to 0.7061 , suggesting the upper mantle could be the source of the granitoids. Two samples of leucogranite with high and very high $87 \mathrm{Sr} / 86 \mathrm{Sr}$ initial ratios 0.7079 and 0.7144 indicate that they are the products of the melting of the crustal rocks. In the Walong area dextral shearing might be synchronous with the intrusion of the copious volume of the leucogranites into the earlier rocks. In the Dibang valley, leucogranites near Dumbuen invariably follow the right lateral shearing in the earlier intrusives. Leucogranite intrusion might be associated with the collision induced shearing towards the later stages in the thick continental crust. 